JURNAL NOMINAL / VOLUME VII NOMOR 2 / TAHUN 2018

\title{
PENGARUH PENGETAHUAN PRODUK TABUNGAN, REPUTASI BANK, DAN PERSEPSI NASABAH MENGENAI SUKU BUNGA SIMPANAN TERHADAP KEPUTUSAN MENABUNG NASABAH
}

\section{THE EFFECT OF SAVINGS PRODUCTS KNOWLEDGE, BANK REPUTATION, AND CUSTOMERS PERCEPTION ON DEPOSIT INTEREST RATE ON THE CUSTOMER SAVING DECISION}

\author{
Ayun Sekar Widowati \\ Prodi Akuntansi Universitas Negeri Yogyakarta \\ ayunsekar7@gmail.com \\ RR. Indah Mustikawati, M.Si., Ak., CA \\ Staf Pengajar Jurusan Pendidikan Akuntansi Universitas Negeri Yogyakarta
}

\begin{abstract}
Abstrak : Pengaruh Pengetahuan Produk Tabungan, Reputasi Bank, Dan Persepsi Nasabah Mengenai Suku Bunga Simpanan Terhadap Keputusan Menabung Nasabah. Penelitian ini bertujuan untuk menganalisis (1) pengaruh Pengetahuan Produk Tabungan terhadap Keputusan Menabung Nasabah pada Bank X Unit Y, (2) pengaruh Reputasi Bank terhadap Keputusan Menabung Nasabah pada Bank X Unit Y, (3) pengaruh Persepsi Nasabah mengenai Suku Bunga Simpanan terhadap Keputusan Menabung Nasabah pada Bank X Unit Y, (4) pengaruh Pengetahuan Produk Tabungan, Reputasi Bank, dan Persepsi Nasabah mengenai Suku Bunga Simpanan terhadap Keputusan Menabung Nasabah pada Bank X Unit Y. Responden dalam penelitian ini adalah 80 nasabah yang memiliki simpanan dalam bentuk tabungan di Bank X Unit Y. Teknik analisis data yang digunakan adalah analisis regresi sederhana dan analisis regresi berganda. Hasil dari penelitian menunjukkan : (1) Pengetahuan Produk Tabungan berpengaruh positif terhadap Keputusan Menabung Nasabah, (2) Reputasi Bank berpengaruh positif terhadap Keputusan Menabung Nasabah, (3) Persepsi Nasabah mengenai Suku Bunga Simpanan berpengaruh positif terhadap Keputusan Menabung Nasabah, (4) Pengetahuan Produk Tabungan, Reputasi Bank, dan Persepsi Nasabah mengenai Suku Bunga Simpanan secara bersama-sama berpengaruh positif terhadap Keputusan Menabung Nasabah.
\end{abstract}

Kata kunci: Pengetahuan Produk Tabungan, Reputasi Bank, Persepsi Nasabah mengenai Suku Bunga Simpanan, Keputusan Menabung Nasabah

Abstract : The Effect Of Savings Products Knowledge, Bank Reputation, And Customers Perception On Deposit Interest Rate On The Customer Saving Decision. This study aims to analyze (1) the influence of Savings Products Knowledge toward Customer Saving Decision at Bank X Unit Y, (2) the influence of Bank Reputation toward Customer Saving Decision at Bank X Unit Y, (3) the influence of Customer Perception on Deposit Interest Rate toward Customer Saving Decision at Bank X Unit Y, (4) the influence of Savings Product Knowledge, Bank Reputation, and Customer Perception on Deposit Interest Rate toward Customer Saving Decision at Bank X Unit Y. Respondents in this research included 80 customers who have saving at Bank X Unit Y. Data analysis technique used a simple linier regression and multiple linier regression. The results of the research are (1) Savings Products Knowledge positively affects toward Customer Saving Decision, (2) Bank Reputation positively affects toward Customer Saving Decision, (3) Customer Perception on Deposit Interest Rate positively affects toward Customer Saving Decision, (4) Saving Products Knowledge, Bank Reputation, and Customer Perception on Deposit Rate simultaneously influence the Customer Saving Decision.

Keywords: Savings Products Knowledge, Bank Reputation, Customer Perception on Deposit Interest Rate, Customer Saving Decision. 


\section{JURNAL NOMINAL / VOLUME VII NOMOR 2 / TAHUN 2018}

\section{Pendahuluan}

Bank merupakan badan usaha yang menghimpun dana dari masyarakat dalam bentuk simpanan, dan menyalurkan kepada masyarakat untuk meningkatkan taraf hidup rakyat banyak. Apabila dilihat dari sejarahnya, kegiatan perbankan pada awalnya dimulai dari jasa penukaran uang (Kasmir, 2013: 27). Kegiatan operasional perbankan kemudian berkembang lagi menjadi tempat penitipan uang yang sekarang disebut dengan kegiatan simpanan. Jasa-jasa bank lainnya menyusul sesuai dengan perkembangan zaman dan kebutuhan masyarakat yang semakin beragam.

Perkembangan dunia perbankan di Indonesia cukup signifikan dari waktu ke waktu. Berdasarkan data Statistik Perbankan per Desember 2017, jumlah bank umum di Indonesia tercatat sebanyak 115 bank dengan jumlah kantor bank umum yang meningkat sebanyak 2.340 dari tahun 2012. Melihat jumlah tersebut, masingmasing bank dihadapkan pada persaingan yang semakin ketat dan kompetitif untuk menjaga kelangsungan usahanya. Demi mencapainya, bank menjalankan fungsi intermediasi sebagai penghimpun dana untuk memperoleh modal agar dapat disalurkan kembali kepada masyarakat melalui kredit. Penghimpunan dana bank berasal dari beberapa sumber antara lain dana sendiri, dana dari deposan (dana pihak ketiga), dana pinjaman, dan sumber dana lain (Budisantosa, 2014: 124).

Kelangsungan hidup perbankan erat kaitannya dengan dana pihak ketiga. Menurut Ikatan Bankir Indonesia (2015: 21), dana pihak ketiga berperan penting dalam menggerakkan semua komponen yang ada pada bank. Sumber dana pihak ketiga tersebut dapat berupa giro, deposito, dan tabungan nasabah perorangan atau badan (Budisantosa, 2014: 124). Perkembangan jumlah perbankan di Indonesia berakibat pada meningkatnya persaingan antarbank dalam upaya memperoleh dana pihak ketiga. Hingga tahun 2017, persaingan bank-bank besar maupun bank-bank kecil untuk memperebutkan dana pihak ketiga berbiaya murah masih terus terjadi. Sumber dana berbiaya murah adalah sumber dana yang memiliki beban biaya, namun tergolong sebagai beban biaya murah. Salah satu sumber dana berbiaya murah adalah tabungan (Leon, 2007: 36).

Melihat semakin ketatnya persaingan di dunia perbankan, maka setiap bank harus memiliki strategi tepat untuk memperoleh dana pihak ketiga berbiaya murah yang memiliki kontribusi yang cukup besar. Kontribusi tabungan dalam meningkatkan dana pihak ketiga (DPK) bank tidak dapat diragukan. Penelitian yang dilakukan oleh Juliandi, dkk (2015) membuktikan bahwa produk-produk 


\section{JURNAL NOMINAL / VOLUME VII NOMOR 2 / TAHUN 2018}

tabungan berpengaruh positif dalam meningkatkan dana pihak ketiga. Di sisi lain, tabungan merupakan instrumen penghimpun dana yang populer di kalangan masyarakat. Hampir seluruh lapisan masyarakat dapat membuka rekening tabungan karena persyaratan yang relatif lebih mudah dan saldo awal yang tidak terlalu besar. Hal tersebut tercermin dari jumlah rekening tabungan per Desember 2017 yang memiliki jumlah terbesar dibandingkan jenis simpanan lain (Lembaga Penjamin Simpanan, 2017).

PT. Bank X yang selalu berusaha mengembangkan strategi guna menjaga kegiatan operasionalnya. Pada tahun 2017, PT. Bank X mengandalkan penghimpunan dana pihak ketiga sebagai sumber pendanaan. Tabungan merupakan dana pihak ketiga yang cukup berkontribusi dalam sumber pendanaan PT. Bank X. Kontribusi tabungan dapat dilihat dari perkembangan jumlah tabungan PT. Bank $\mathrm{X}$ yang mengalami peningkatan selama empat tahun terakhir.

Perkembangan jumlah tabungan PT. Bank X tidak terlepas dari peran kantor cabang sebagai salah satu alternatif dalam memperoleh dana pihak ketiga. Salah satu kantor dari PT. Bank X yang berperan dalam memperoleh dana pihak ketiga adalah Bank $\mathrm{X}$ Unit $\mathrm{Y}$ yang terletak di Daerah Istimewa Yogyakarta. Bank X Unit Y mampu menghimpun dana masyarakat dari berbagai kalangan.

Pada dasarnya masyarakat akan memilih bank yang memberikan keuntungan dan kemudahan, sehingga bank harus memperhatikan keinginan dan kebutuhan masyarakat dari waktu ke waktu. Produk dan stimulus bank yang sesuai dengan keinginan dan kebutuhan masyarakat, dapat mendorong masyarakat untuk membuat keputusan menabung. Dengan demikian, penting bagi bank untuk menjaga dan mengembangkan produk/jasa, proses, manusia, dan aspek lain yang memengaruhi masyarakat sebagai pembuat keputusan.

Produk merupakan salah satu strategi bank untuk memperoleh nasabah. Produk-produk tabungan yang ditawarkan oleh masing-masing bank kian bertambah seiring dengan banyaknya jumlah lembaga perbankan yang ada, sehingga masyarakat harus mengenali kebutuhan dan selukbeluk produk yang ditawarkan dengan lebih baik. Pemahaman dan pengetahuan nasabah penyimpan mengenai produk sangat penting, karena pengetahuan merupakan dasar keputusan nasabah sebagai konsumen bank.

Pengetahuan nasabah tentang produk akan menjadi faktor yang digunakan untuk mempertimbangkan keputusan menabung. Akan tetapi, survei yang dilakukan Otoritas Jasa Keuangan (OJK) pada tahun 2016 menemukan hasil 


\section{JURNAL NOMINAL / VOLUME VII NOMOR 2 / TAHUN 2018}

bahwa, indeks literasi (pengetahuan) keuangan di Indonesia hanya 29,66\%. Indeks literasi tersebut tergolong rendah jika dibandingkan dengan Malaysia, Singapura, Thailand, dan Filiphina. Masyarakat di Indonesia dinilai belum begitu memahami produk-produk keuangan, seperti bank, asuransi, dan pasar modal. Padahal, ketika masyarakat memiliki pengetahuan produk keuangan dan menjadikannya prinsip dalam pengambilan keputusan, maka semakin tinggi kepercayaan masyarakat dalam perencanaan tabungan masa depan (Brown \& Graf, 2013:11).

Reputasi dapat menjadi aspek yang harus diperhatikan oleh bank. Salah satu alasan utama konsumen membuat keputusan menabung adalah reputasi bank. Penelitian yang dilakukan Almossawi (1991) menyatakan bahwa salah satu atribut penting yang dipertimbangkan nasabah adalah reputasi bank. Kewajiban dalam mengelola reputasi perusahaan menjadi tanggung jawab bersama seluruh bagian dalam perusahaan. Akan tetapi, mengelola reputasi bukan menjadi hal yang mudah, bahkan kehilangan reputasi lebih mudah dibandingkan usaha untuk membangun reputasi tersebut. Reputasi perusahaan dapat hancur dalam sekejap melalui sebuah pemberitaan buruk yang menyangkut nama perusahaan (Nova, 2011: 307).

Maraknya kasus kejahatan perbankan yang terjadi pada sejumlah bank di Indonesia berimbas terhadap risiko reputasi bank terkait. Wawancara yang dilakukan oleh peneliti terhadap beberapa nasabah penyimpan di Bank $\mathrm{X}$ Unit $\mathrm{Y}$ memberikan hasil bahwa sebagian besar nasabah menyatakan alasan utama menabung di bank adalah faktor keamanan dan dilandasi oleh kepercayaan nasabah terhadap bank. Berdasarkan pengungkapan alasan tersebut, tidak dapat dipungkiri apabila nasabah penyimpan yang menjadi korban kejahatan perbankan lebih memilih untuk melakukan pemblokiran rekening, atau bahkan memutuskan hubungan dengan bank terkait. Kasus-kasus perbankan yang terjadi dapat mengakibatkan turunnya kepercayaan nasabah. Dengan demikian, reputasi bank dapat memberikan pengaruh pada perilaku dan keputusan pelanggan karena layanan yang ditawarkan oleh bank bersifat tidak berwujud (Rosa, 2012: 400).

Kegiatan operasional perbankan juga tidak lepas dari suku bunga, baik bunga pinjaman maupun bunga simpanan. Bunga simpanan merupakan salah satu faktor yang seringkali dipertimbangkan oleh masyarakat sebelum menginvestasikan dananya di bank. Suku bunga yang tinggi akan mendorong investor untuk menanamkan dananya di bank daripada menginvestasikannya pada sektor produksi atau industri yang memiliki tingkat risiko lebih besar (Khalwaty, 2000: 
144). Ketika tingkat suku bunga tinggi atau naik maka volume tabungan di bank akan naik, sedangkan pada tingkat suku bunga rendah cenderung akan mengurangi volume tabungan di bank. Minat nasabah untuk menabung di bank cenderung lebih tinggi ketika tingkat suku bunga naik dengan harapan return yang akan diterima nasabah juga akan naik (Darmawi, 2006:181). Keadaan tersebut berarti bahwa bunga akan memengaruhi jumlah simpanan di bank. Dengan demikian, sumber dana dan kelangsungan usaha bank juga tergantung pada suku bunga simpanan.

Usaha untuk menarik nasabah penyimpan melalui suku bunga berakibat pada tingginya suku bunga dana perbankan dan dinilai telah melebihi batas kewajaran. Otoritas Jasa Keuangan (OJK) kemudian menetapkan batas maksimum suku bunga dana pihak ketiga (DPK) mulai Oktober 2014 untuk menurunkan suku bunga simpanan. Meskipun tingkat suku bunga simpanan terus menyusut, dana pihak ketiga (DPK) yang bersumber dari tabungan masyarakat justru terus mengalami kenaikan (Laucereno, 2017). Keadaan tersebut dapat berarti bahwa bunga simpanan tidak lagi berpengaruh terhadap keputusan menabung.

Hasil penelitian Priyadi \& Taufiq (2016: 228) menemukan bahwa suku bunga tabungan tidak lagi berpengaruh terhadap tabungan masyarakat. Berbeda dengan hasil penelitian Juwanita (2015: 100) yang memberikan hasil bahwa Persepsi Nasabah mengenai Suku Bunga Simpanan mendorong minat menabung. Dengan demikian, terjadi perbedaan hasil penelitian terdahulu mengenai pengaruh suku bunga simpanan terhadap kegiatan menabung.

Berdasarkan permasalahan dan adanya research gap di atas, penulis tertarik untuk menganalisis pengaruh Pengetahuan Produk Tabungan, Reputasi Bank, dan Persepsi Nasabah mengenai Suku Bunga Simpanan terhadap Keputusan Menabung Nasabah dengan judul "Pengaruh Pengetahuan Produk Tabungan, Reputasi Bank, dan Persepsi Nasabah mengenai Suku Bunga Simpanan terhadap Keputusan Menabung Nasabah pada Bank X Unit Y’.

\section{METODE PENELITIAN}

\section{Jenis Penelitian}

Penelitian ini merupakan penelitian kausal komparatif yakni hubungan yang bersifat sebab akibat. (Sugiyono, 2010: 11). Pendekatan dalam penelitian ini adalah pendekatan kuantitatif.

\section{Waktu dan Tempat Penelitian}

Penelitian ini dilakukan di Bank X Unit Y. Waktu pelaksanaan penelitian adalah bulan Januari 2018 sampai dengan April 2018.

\section{Populasi Penelitian}

Populasi dalam penelitian ini adalah nasabah yang memiliki simpanan dalam 


\section{JURNAL NOMINAL / VOLUME VII NOMOR 2 / TAHUN 2018}

bentuk tabungan di Bank X Unit Y. Teknik pengambilan sampel menggunakan convenience sampling (sampling aksidental) yakni sampel yang diambil dari orang-orang yang kebetulan ada (Soeratno, 2008: 112). Jumlah sampel dalam penelitian ini sebanyak 80 nasabah yang memiliki simpanan dalam bentuk tabungan di Bank X Unit Y.

\section{Prosedur}

Teknik pengumpulan data dalam penelitian ini menggunakan angket (kuesioner). Kuesioner digunakan untuk mengetahui adanya pengaruh Pengetahuan Produk Tabungan, Reputasi Bank, dan Persepsi Nasabah mengenai Suku Bunga Simpanan terhadap Keputusan Menabung Nasabah. Skor dari jawaban responden untuk setiap pertanyaan menggunakan skala likert yang dimodifikasi 4 alternatif jawaban menjadi skala 1 sampai 4.

Sebelum dilakukan uji hipotesis, kuesioner terlebih dahulu untuk dilakukan uji validtas dan realibiltas. Selanjutnya kuesioner didistribusikan kepada 89 nasabah, namun kuesioner yang dapat diolah dan digunakan untuk uji hipotesis sebanyak 80 kuesioner.

\section{Teknik Analisis Data}

Uji hipotesis dilakukan dengan menggunakan: 1) analisis regresi linear sederhana digunakan untuk menguji hipotesis pertama, kedua dan ketiga, yakni dengan menyusun persamaan regresi, mencari koefisien determinasi $\left(\mathrm{R}^{2}\right)$, dan uji t diperlukan untuk menguji pengaruh dari setiap variabel independen terhadap variabel dependen. 2) analisis regresi berganda dilakukan untuk menguji pengaruh simultan dari Pengetahuan Produk Tabungan, Reputasi Bank, dan Persepsi Nasabah mengenai Suku Bunga Simpanan terhadap Keputusan Menabung Nasabah. Analisis regresi linear berganda dalam penelitian ini digunakan untuk menguji hipotesis empat, yakni dengan menyusun persamaan regresi, mencari koefisien determinasi $\left(\mathrm{R}^{2}\right)$, dan uji $\mathrm{F}$ untuk menguji pengaruh variabel independen terhadap variabel dependen secara simultan.

\section{HASIL PENELITIAN DAN} PEMBAHASAN

\section{Hasil Penelitian}

Analisis deskripsi data yang disajikan dalam penelitian ini meliputi Minimum, Maksimum, Mean (M), dan Standar Deviasi (SD). 
JURNAL NOMINAL / VOLUME VII NOMOR 2 / TAHUN 2018

Tabel 1. Hasil Analisis Deskriptif

\begin{tabular}{cccccc}
\hline Var & $\mathbf{N}$ & Min & Max & M & SD \\
\hline $\mathbf{X}_{1}$ & 80 & 19 & 31 & 24, & 2,8 \\
& & & & 28 & 01 \\
\hline $\mathbf{X}_{2}$ & 80 & 30 & 41 & 33, & 2,6 \\
& & & & 95 & 33 \\
\hline $\mathbf{X}_{3}$ & 80 & 12 & 24 & 17, & 2,4 \\
& & & & 28 & 80 \\
\hline $\mathbf{Y}$ & 80 & 20 & 30 & 24, & 2,4 \\
& & & & 49 & 02
\end{tabular}

Sumber: Data Primer Diolah

Variabel $\mathrm{X}_{1} \quad$ adalah

Pengetahuan Produk Tabungan dengan skor tertinggi 31, sedangkan skor terendah 19. Mean 43,964, dan Standar Deviasi 2,035. Variabel $\mathrm{X}_{2}$ adalah Reputasi Bank dengan skor tertinggi 41, skor terendah 30. Mean 33,95, dan Standar Deviasi 2,633. Variabel $\mathrm{X}_{3}$ adalah Persepsi Nasabah mengenai Suku Bunga Simpanan dengan skor tertinggi 24, skor terendah 12. Mean 17,28, dan Standar Deviasi 2,480. Variabel dependen (Y) adalah Keputusan Menabung Nasabah dengan skor tertinggi 30 , skor terendah 20. Mean 24,49, dan Standar Deviasi 2,402.

Hasil uji hipotesis adalah: 1) Analisis regresi sederhana digunakan untuk mengetahui hubungan variabel independen secara parsial terhadap variabel dependen. Analisis regresi sederhana untuk menguji hipotesis pertama hingga ketiga.
Tabel 2. Analisis Regresi H1, H2, H3

\begin{tabular}{ccccccc}
\hline Va & Kon & Koef & \multicolumn{2}{c}{ Nilai R } & $\mathbf{t}_{\text {hit }}$ & Sig \\
\cline { 5 - 6 } $\mathbf{r}$ & $\mathbf{s}$ & $\mathbf{R e g}$ & $\mathbf{R}$ & $\mathbf{R}^{\mathbf{2}}$ & & \\
ung & \\
\hline $\mathbf{X}_{\mathbf{1}}$ & 13, & 0,4 & 0,5 & 0,2 & 5, & 0,0 \\
$\mathbf{- Y}$ & 865 & 38 & 10 & 60 & 23 & 00 \\
& & & & & 9 & \\
\hline $\mathbf{X}_{2}$ & 9,6 & 0,4 & 0,4 & 0,2 & 4, & 0,0 \\
$\mathbf{- Y}$ & 17 & 38 & 80 & 30 & 83 & 00 \\
& & & & & 4 & \\
\hline $\mathbf{X}$ & 16, & 0,4 & 0,4 & 0,2 & 4, & 0,0 \\
$\mathbf{- Y}$ & 266 & 76 & 91 & 41 & 98 & 00 \\
& & & & & 2 & \\
\hline
\end{tabular}

Sumber : Data Primer Diolah

H1 : Pengetahuan Produk Tabungan berpengaruh positif terhadap

\section{Keputusan Menabung Nasabah.}

Berdasarkan tabel tersebut dapat disusun persamaan regresi sebagai berikut :

$$
\mathrm{Y}=13,865+0,438 \mathrm{X}_{1}
$$

Persamaan tersebut memiliki makna yakni, jika Pengetahuan Produk Tabungan $\left(\mathrm{X}_{1)}\right.$ dianggap tidak mengalami perubahan (konstan), maka Keputusan Menabung Nasabah (Y) akan tetap memiliki nilai sebesar 13,865. Selain itu, koefisien regresi bertanda positif sebesar 0,438 menunjukkan bahwa Pengetahuan Produk Tabungan berpengaruh positif terhadap Keputusan Menabung Nasabah. Setiap kenaikan variabel Pengetahuan Produk Tabungan sebesar 1 satuan akan menaikkan variabel Keputusan Menabung Nasabah sebesar 0,438 satuan, dengan asumsi faktor 
lain adalah tetap. Jika dilihat dari nilai $\mathrm{R}$ Square sebesar 0,260, artinya besarnya pengaruh Pengetahuan Produk Tabungan terhadap Keputusan Menabung Nasabah adalah sebesar $26 \%$, dan $74 \%$ dipengaruhi oleh variabel lain.

Nilai t hitung sebesar 5,239 yang nilainya lebih besar dari t tabel yaitu 1,665. Hasil uji $\mathrm{t}$ statistik untuk variabel Pengetahuan Produk Tabungan memberikan nilai signifikan lebih kecil dari $0,05(0,000<0,05)$. Dengan demikian, dapat disimpulkan bahwa Pengetahuan Produk Tabungan berpengaruh positif terhadap Keputusan Menabung Nasabah. Semakin baik pengetahuan produk yang dimilki nasabah maka semakin kuat pula keputusan menabung. Berdasarkan hasil uji regresi linear sederhana tersebut dapat disimpulkan bahwa hipotesis pertama yang menyatakan bahwa adanya pengaruh positif Pengetahuan Produk Tabungan terhadap Keputusan Menabung Nasabah diterima.

\section{H2 : Reputasi Bank berpengaruh positif} terhadap Keputusan Menabung Nasabah.

Berdasarkan tabel tersebut dapat disusun persamaan regresi sebagai berikut :

$$
\mathrm{Y}=9617+0,438 \mathrm{X}_{2}
$$

Persamaan tersebut memiliki makna yakni, jika Reputasi Bank $\left(\mathrm{X}_{2}\right)$ dianggap tidak mengalami perubahan (konstan), maka Keputusan Menabung Nasabah (Y) akan tetap memiliki nilai sebesar 9,617.
Selain itu, koefisien regresi bertanda positif sebesar 0,438 menunjukkan bahwa Reputasi Bank berpengaruh positif terhadap Keputusan Menabung Nasabah. Setiap kenaikan variabel Reputasi Bank sebesar 1 satuan akan menaikkan variabel Keputusan Menabung Nasabah sebesar 0,438 satuan, dengan asumsi faktor lain adalah tetap. Jika dilihat dari nilai R Square sebesar 0,230, artinya besarnya pengaruh Pengetahuan Produk Tabungan terhadap Keputusan Menabung Nasabah adalah sebesar 23\%, dan $77 \%$ dipengaruhi oleh variabel lain.

Nilai t hitung sebesar 4,384 lebih besar dari t tabel yaitu 1,665. Hasil uji $t$ statistik untuk variabel Reputasi Bank memberikan nilai signifikan lebih kecil dari $0,05(0,000<0,05)$. Dengan demikian dapat disimpulkan bahwa Reputasi Bank berpengaruh positif terhadap Keputusan Menabung Nasabah. Semakin baik reputasi yang dimiliki bank maka semakin kuat pula keputusan menabung. Berdasarkan hasil uji regresi linear sederhana tersebut dapat disimpulkan bahwa hipotesis kedua yang menyatakan bahwa adanya pengaruh positif Reputasi Bank terhadap Keputusan Menabung Nasabah diterima.

H3 : Persepsi Nasabah mengenai Suku Bunga Simpanan berpengaruh positif terhadap Keputusan Menabung Nasabah. 
Berdasarkan tabel tersebut dapat disusun persamaan regresi sebagai berikut :

$$
Y=16,266+0,476 X_{3}
$$

Persamaan tersebut memiliki makna yakni, jika nilai Persepsi Nasabah mengenai Suku Bunga Simpanan $\left(X_{3}\right)$ dianggap tidak mengalami perubahan (konstan), maka Keputusan Menabung Nasabah (Y) akan tetap memiliki nilai sebesar 16,266. Selain itu, koefisien regresi bertanda positif sebesar 0,476 menunjukkan bahwa Persepsi Nasabah mengenai Suku Bunga Simpanan berpengaruh positif terhadap Keputusan Menabung Nasabah. Setiap kenaikan variabel Persepsi Nasabah mengenai Suku Bunga Simpanan sebesar 1 satuan akan menaikkan variabel Keputusan Menabung Nasabah sebesar 0,476 satuan, dengan asumsi faktor lain adalah tetap. Jika dilihat dari nilai $\mathrm{R}$ Square sebesar 0,241, artinya besarnya pengaruh Persepsi Nasabah mengenai Suku Bunga Simpanan terhadap Keputusan Menabung Nasabah adalah sebesar $24,1 \%$, dan $75,9 \%$ dipengaruhi oleh variabel lain.

Nilai thitung sebesar 4,982 yang lebih besar dari $\mathrm{t}$ tabel yaitu 1,665. Hasil uji $\mathrm{t}$ statistik untuk variabel Reputasi Bank memberikan nilai signifikan lebih kecil dari $0,05(0,000<0,05)$. Dengan demikian dapat disimpulkan bahwa Persepsi Nasabah mengenai Suku Bunga Simpanan berpengaruh positif terhadap Keputusan

Menabung Nasabah. Semakin baik persepsi nasabah mengenai suku bunga simpanan yang diberikan bank, maka semakin kuat pula keputusan menabung. Berdasarkan hasil uji regresi linear sederhana tersebut dapat disimpulkan bahwa hipotesis ketiga yang menyatakan bahwa adanya pengaruh positif Persepsi Nasabah mengenai Suku Bunga Simpanan terhadap Keputusan Menabung Nasabah diterima.

2) Analisis regresi berganda dilakukan untuk menguji pengaruh simultan dari beberapa variabel independen terhadap satu variabel dependen.

H4 : Pengetahuan Produk Tabungam, Reputasi Bank, dan Persepsi Nasabah mengenai Suku Bunga Simpanan berpengaruh positif terhadap Keputusan Menabung Nasabah.

Berdasarkan hasil regresi linier berganda yang dilakukan maka diperoleh tabel berikut:

Tabel 3. Analisis Regresi H4

\begin{tabular}{lc}
\hline Variabel & Koefisien Regresi \\
\hline Konstanta & 0,703 \\
\hline $\mathbf{X}_{\mathbf{1}}$ & 0,299 \\
\hline $\mathbf{X}_{\mathbf{2}}$ & 0,355 \\
\hline $\mathbf{X}_{\mathbf{3}}$ & 0,258 \\
\hline $\mathbf{R}$ & 0,704 \\
\hline R Square & 0,496 \\
\hline F hitung & 24,930 \\
\hline F Tabel & 2,72 \\
\hline Sig F & 0,000 \\
\multicolumn{2}{c}{ Sumber : Data Primer Diolah }
\end{tabular}




\section{JURNAL NOMINAL / VOLUME VII NOMOR 2 / TAHUN 2018}

Berdasarkan hasil analisis regresi linier berganda dapat disusun persamaan regresi sebagai berikut :

$$
\begin{gathered}
Y=0,703+0,299 X_{1}+0,355 X_{2}+ \\
0,258 X_{3}
\end{gathered}
$$

Persamaan tersebut memiliki makna yakni nilai konstanta sebesar 0,703 menunjukkan bahwa apabila semua variabel independen dianggap tetap, maka Keputusan Menabung Nasabah sebesar 0,703. Setiap kenaikan variabel independen Pengetahuan Produk Tabungan $\left(\mathrm{X}_{1}\right)$ sebesar 1 satuan, maka akan menaikkan variabel Keputusan Menabung Nasabah sebesar 0,299 satuan dengan asumsi bahwa variabel independen lain adalah tetap. Setiap kenaikan variabel independen Reputasi Bank $\left(\mathrm{X}_{2}\right)$ sebesar 1 satuan, maka akan menaikkan variabel Keputusan Menabung Nasabah sebesar 0,355 satuan dengan asumsi bahwa variabel independen lain adalah tetap. Setiap kenaikan variabel independen Persepsi Nasabah mengenai Bunga Simpanan $\left(\mathrm{X}_{3}\right)$ sebesar 1 satuan, maka akan menaikkan variabel Keputusan Menabung Nasabah sebesar 0,258 satuan dengan asumsi bahwa variabel independen lain adalah tetap.

Selain itu, dapat dilihat nilai korelasi regresi (R) yang bernilai positif sebesar 0,704. Maka dapat diartikan bahwa variabel-variabel tersebut memiliki hubungan yang positif.
Berdasarkan data pada tabel hasil analisis regresi linier berganda tersebut diperoleh $F_{\text {hitung }}$ sebesar 24,930 sedangkan $F_{\text {tabel }}$ sebesar 2,72. Apabila dilihat dari nilai probabilitas lebih kecil dari $0,05(0,000<$ 0,05). Nilai $F_{\text {hitung }}>F_{\text {tabel }}$ dan nilai probabilitas signifikansi $<0,05$ berarti bahwa Pengetahuan Produk Tabungan, Reputasi Bank, dan Persepsi Nasabah mengenai Suku Bunga Simpanan secara simultan berpengaruh positif terhadap Keputusan Menabung Nasabah. Dengan demikian dapat disimpulkan bahwa hipotesis keempat yang menyatakan bahwa adanya pengaruh positif Pengetahuan Produk Tabungan, Reputasi Bank, dan Persepsi Nasabah mengenai Suku Bunga Simpnan terhadap Keputusan Menabung Nasabah diterima.

\section{Pembahasan}

a) Pengaruh Pengetahuan Produk Tabungan terhadap Keputusan Menabung Nasabah

Hasil penelitian ini mendukung hipotesis pertama yang menyatakan bahwa Pengetahuan Produk Tabungan berpengaruh psoitif terhadap Keputusan Menabung Nasabah. Hal ini dibuktikan dengan uji t yang menunjukkan bahwa $t$ hitung lebih besar dari t tabel $(5,239>$ 1,665) dan nilai probabilitas signifikan 0,000 dan lebih kecil dari 0,05 sehingga dapat disimpulkan bahwa Pengetahuan Produk Tabungan berpengaruh positif 


\section{JURNAL NOMINAL / VOLUME VII NOMOR 2 / TAHUN 2018}

terhadap Keputusan Menabung

Nasabah.

Hasil penelitian ini mengindikasikan bahwa pengetahuan sangat penting bagi manusia. Semakin luas pengetahuan yang dimiliki, maka semakin luas pula pemikiran seseorang tentang suatu hal. Ketika konsumen memiliki pengetahuan lebih banyak, maka konsumen dapat mengambil keputusan dengan lebih baik, serta lebih efisien dan tepat dalam mengolah informasi (Sumarwan, 2011: 147).

Melalui pengetahuan mengenai produk tabungan yang dimiliki, nasabah dapat membuat keputusan menabung yang kuat. Pengetahuan tersebut dapat mendorong nasabah memutuskan produk tabungan yang sesuai dengan kebutuhan, mengorbankan waktu dan biaya, hingga keinginan untuk mempertahankan rekening tabungan yang dimilikinya. Hasil penelitian diperkuat dengan penelitian terdahulu yang dilakukan oleh Dewi (2015) dan Diana (2017) yang menyatakan bahwa Pengetahuan Produk Tabungan berpengaruh positif dan signifikan terhadap Keputusan Menjadi Nasabah.

\section{b) Pengaruh Reputasi Bank terhadap}

\section{Keputusan Menabung Nasabah}

Hasil penelitian ini mendukung hipotesis kedua yang menyatakan bahwa Reputasi Bank berpengaruh positif terhadap Keputusan

Menabung Nasabah. Hal ini dibuktikan dengan hasil uji t yang dilakukan menunjukkan bahwa $\mathrm{t}$ hitung lebih besar dari t tabel sebesar $(4,384>1,665)$ dan nilai probabilitas signifikan 0,000 dan lebih kecil dari 0,05 sehingga dapat disimpulkan bahwa Reputasi Bank berpengaruh positif terhadap Keputusan Menabung Nasabah.

Hasil penelitian ini mengindikasikan bahwa reputasi menjadi alasan nasabah dalam mempertahankan hubungannya dengan bank. Reputasi baik yang dimiliki bank menjadi dasar kepercayaan nasabah penyimpan untuk tetap menggunakan jasa simpanan dan membuat keputusan menabung. Reputasi bank dianggap penting oleh nasabah untuk tetap mempercayakan dana yang mereka miliki dikelola oleh bank terkait. Hal tersebut sejalan dengan pendapat Lau dan Lee (1999: 347) yang menganggap bahwa reputasi merupakan faktor terpenting dari karakteristik perusahaan yang membentuk kepercayaan pelanggan. Reputasi bank juga merupakan aset terbesar bank, mengingat produk yang ditawarkan bank bersifat tidak berwujud (Rosa, 2012: 400).

Hasil penelitian sejalan dengan penelitian terdahulu yang dilakukan oleh 
Rohmah (2015) yang menyatakan bahwa

Reputasi Bank berpengaruh positif dan signifikan terhadap Keinginan Nasabah menambah Tabungan Mudharabah. Gambaran akan citra baik di mata masyarakat menciptakan persepsi positif di mata masyarakat dan nasabah terhadap reputasi bank (Rohmah, 2015: 113). Penelitian yang dilakukan Rosa (2012: 400) juga menemukan bahwa reputasi bank memberikan pengaruh pada sikap dan keputusan pelanggan.

c) Pengaruh Persepsi Nasabah mengenai Suku Bunga Simpanan terhadap Keputusan Menabung Nasabah

Hasil penelitian ini mendukung hipotesis ketiga yang menyatakan bahwa Persepsi Nasabah mengenai Suku Bunga Simpanan berpengaruh positif terhadap Keputusan Menabung Nasabah. Hal ini dibuktikan dengan hasil uji t yang dilakukan menunjukkan bahwa $\mathrm{t}$ hitung besar dari t tabel (4,982 > 1,665) dan nilai probabilitas signifikan 0,000 dan lebih kecil dari 0,05 sehingga dapat disimpulkan bahwa Persepsi Nasabah mengenai Suku Bunga Simpanan berpengaruh positif terhadap Keputusan Menabung Nasabah.

Penelitian ini memberikan hasil bahwa informasi mengenai tingkat bunga simpanan yang diterima nasabah terkait dengan tingkat bunga, jenis, dan fungsi suku bunga simpanan diterima dan interpretasikan dengan cukup baik. Kebijakan penetapan maksimum suku bunga simpanan oleh Otoritas Jasa Keuangan (OJK) yang berakibat terus menurunnya suku bunga simpanan tidak memberikan dampak signifikan. Suku bunga simpanan yang diberikan bank masih dianggap menarik dan sesuai dengan fungsinya sebagai salah satu stimulus untuk menarik nasabah.

Hasil penelitian ini didukung oleh penelitian yang dilakukan Astuti (2013), Atmadha (2013), dan Juwanita (2015) . Hasil dari penelitian-penelitian tersebut menyatakan bahwa persepsi nasabah mengenai tingkat suku bunga simpanan berpengaruh positif terhadap minat menabung nasabah.

d) Pengaruh Pengetahuan Produk Tabungan, Reputasi Bank, dan Persepsi Nasabah mengenai Suku Bunga Simpanan terhadap Keputusan Menabung Nasabah Hasil penelitian ini mendukung hipotesis keempat yang menyatakan bahwa Pengetahuan Produk Tabungan, Reputasi Bank, dan Persepsi Nasabah mengenai 


\section{JURNAL NOMINAL / VOLUME VII NOMOR 2 / TAHUN 2018}

Suku Bunga Simpanan secara simultan berpengaruh positif terhadap Keputusan Menabung Nasabah. Hal ini dibuktikan dengan nilai $F_{\text {hitung }}>F_{\text {tabel }}$ yaitu 24,930 > 2,72 dan nilai signifikansi $0,000<$ 0,05 yang dapat diartikan bahwa Pengetahuan Produk Tabungan, Reputasi Bank, dan Persepsi Nasabah mengenai Suku Bunga Simpanan secara bersama-sama berpengaruh positif terhadap Keputusan Menabung Nasabah.

$$
\text { Pengetahuan Produk }
$$

Tabungan merupakan semua informasi yang disimpan dalam ingatan nasabah tentang berbagai macam produk dan jasa atau layanan tabungan, pengetahuan lain yang terkait dengan produk dan jasa atau layanan tabungan, dan informasi yang berhubungan dengan fungsinya sebagai nasabah. Semakin baik tingkat pengetahuan yang dimiliki nasabah, maka semakin tinggi keyakinan dan kepercayaan nasabah untuk mengivestasikan dana yang dimiliki dalam bentuk tabungan di bank.

Reputasi bank merupakan karakteristik suatu bank yang terbentuk dari pandangan pihak yang terlibat dengan bank yang menjadikannya unggul dan kompetitif dibandingkan bank lain. Reputasi baik yang dimiliki bank menjadi dasar kepercayaan nasabah penyimpan untuk tetap menggunakan jasa simpanan dan membuat keputusan menabung. Reputasi bank dianggap penting oleh nasabah untuk tetap mempercayakan dana yang mereka miliki dikelola oleh bank terkait. Semakin baik reputasi yang dimiliki bank dari pandangan nasabah, maka semakin kuat keputusan yang diambil nasabah untuk menabung di bank.

Persepsi Nasabah mengenai Suku Bunga Simpanan merupakan cara pandang yang berbeda terhadap suku bunga yang diterima nasabah sebagai balas jasa atas simpanan yang dimilikinya dari bank berdasarkan prinsip konvensional. Informasi mengenai tingkat bunga simpanan yang diterima nasabah terkait dengan tingkat bunga, jenis, dan fungsi bunga simpanan diterima dan interpretasikan dengan cukup baik. Selain itu, nasabah juga mengharapkan imbal hasil dari dana yang mereka simpan di bank dalam bentuk tabungan. Persepsi yang baik tersebut mendorong nasabah 


\section{JURNAL NOMINAL / VOLUME VII NOMOR 2 / TAHUN 2018}

untuk membuat keputusan menabung.

\section{Penutup}

\section{Simpulan}

Pengetahuan Produk Tabungan berpengaruh positif terhadap Keputusan Menabung Nasabah dengan kontribusi sebesar 26\%. Reputasi Bank berpengaruh positif terhadap Keputusan Menabung Nasabah dengan kontribusi sebesar $23 \%$. Persepsi Nasabah mengenai Suku Bunga Simpanan berpengaruh positif terhadap Keputusan Menabung Nasabah dengan kontribusi sebesar $24,1 \%$. Pengetahuan Produk Tabungan, Reputasi Bank, dan Persepsi Nasabah mengenai Suku Bunga Simpanan secara bersama-sama berpengaruh positif terhadap Keputusan Menabung Nasabah dengan memberikan kontribusi $49,6 \%$ dan sisanya $50,4 \%$ dipengaruhi oleh variabel lain di luar penelitian.

\section{Saran}

Berdasarkan hasil analisis regresi yang diperoleh, diketahui bahwa Pengetahuan Produk Tabungan, Reputasi Bank, dan Persepsi Nasabah mengenai Suku Bunga Simpanan memberikan kontribusi sebesar 49,6\%. Dengan demikian, diharapkan Bank X Unit Y dapat memberikan upaya lain untuk meningkatkan keputusan menabung. Misalnya dengan meningkatkan layanan dalam pemberian informasi produk tabungan, meningkatkan kinerja karyawan, dan mempertahankan suku bunga simpanan yang dapat bersaing.

Untuk peneliti selanjutnya diharapkan dapat menambahkan variabelvariabel yang lain yang dapat mempengaruhi keputusan menabung selain variabel yang diangkat dalam penelitian ini. Diharapkan penelitian selanjutnya dapat melengkapi teknik pengumpulan data yang digunakan serta mampu memperluas populasi dan sampel penelitian

\section{DAFTAR PUSTAKA}

Almossawi. (2001). Bank Selection Criteria Employed By College Students In Bahrain: An Emperical Analysis. The International Journal of Bank Marketing, Vol.19 No. 3, pp 115.

Atmadha, A. P. (2013). Pengaruh Persepsi Nasabah Mengenai Lembaga Penjamin Simpanan (LPS) dan Suku Bunga Simpanan terhadap Minat Nasabah dalam Menyimpan Dananya pada Bank Mandiri Yogyakarta Cabang Universitas Negeri Yogyakarta. Skripsi. Universitas Negeri Yogyakarta.

Astuti, T. (2013). Pengaruh Persepsi Nasabah Tentang Tingkat Suku Bunga, Promosi Dan Kualitas Pelayanan Terhadap Minat Menabung Nasabah (Studi Kasus Pada BRI Cabang Sleman). Skripsi. Universitas Negeri Yogyakarta. 
Budisantosa, T. \& Nuritomo. (2014). Bank dan Lembaga Keuangan Lain (Edisi 3). Jakarta: Salemba Empat.

Brown, M \& Graf, F. (2013). Financial Literacy and Retirement Planning in Switzerland. Numeracy, Vol 6, Issue 2, Article 6.

Darmawi, H. (2006). Pasar Finansial dan Lembaga-Lembaga Finansial. Jakarta: PT. Bumi Aksara.

Dewi, N. (2015). Pengaruh Pengetahuan Produk Tabungan dan Nisbah Bagi Hasil terhadap Keputusan Menjadi Nasabah di BTM Mentari Ngunut Tulungagung. Skripsi. Institut Agama Islam Negeri (IAIN) Tulungagung.

Diana, S. M. (2017). Pengaruh Pengetahuan, Lokasi, Kualitas Pelayanan Dan Bagi Hasil Terhadap Keputusan Anggota Menabung di BMT Bina Umat Sejahtera Kalijambe. Skripsi. Institut Agama Islam Negeri Surakarta.

Ikatan Bankir Indonesia. (2015). Memahami Audit Intern Perbankan. Jakarta: Gramedia Pustaka Utama.

Juliandi, Y., Lau, E. A \& Mardiana (2015). Pengaruh Tabungan terhadap Peningkatan Dana Pihak Ketiga (DPK) Bank Pembangunan Daerah Kalimantan Timur pada tahun 2010-2012. Jurnal Ekonomia, Vol. 4, No.2.

Juwanita, E. (2015). Pengaruh Persepsi Nasabah Mengenai Lembaga Penjamin Simpanan (LPS) dan Tingkat Suku Bunga Simpanan terhadap Minat Menabung Nasabah pada Bank dengan Citra Perbankan sebagai Variabel Moderasi (Studi Kasus pada PT Bank Rakyat Indonesia (Persero) Tbk. Cabang
Adisucipto Yogyakarta). Skripsi. Universitas Negeri Yogyakarta.

Kasmir. (2013). Bank dan Lembaga Keuangan Lainnya. Jakarta: Rajawali Pers.

Khalwaty, T. (2000). Inflasi dan Solusinya. Jakarta: PT. Gramedia Pustaka Utama.

Lau, G. T., \& Lee, S. H. (1999). Consumer's Trust in a Brand and the Link to Brand Loyality. Journal of Market Focused Management, hal 341-370.

Laucereno, S. F. (2017). Bunga Turun Kok Simpanan Bank Naik? Ini Jawabannya. Diakses dari http://www.m.detik.com, pada tanggal 3 Januari 2018.

Lembaga Penjamin Simpanan. (2017). Distribusi Simpanan Bank Umum Periode Desember 2017.

Leon, B \& Sonny, E. (2007). Manajemen Aktiva Pasiva Bank Nondevisa. Jakarta: Grasindo.

Nova, F. (2011). Crisis Public Relations: Strategi PR Menghadapi Krisis, Mengelola Isu, Membangun Citra, dan Reputasi Perusahaan. Jakarta: Rajawali Pers.

Otoritas Jasa Keuangan. (2014). Siaran Pers SP-28 DKNS/OJK/2014 tentang OJK Tetapkan Batas Atas Suku Bunga Dana Perbankan. . (2017). Siaran Pers SP/O7/DKNS/OJK/I/2017 tentang OJK: Indeks Literasi dan Inklusi Keuangan Meningkat. .(2017). Statistik Perbankan Indonesia Vol. 16, No. 1 Desember 2017. 
Priyadi, U. \& Taufiq, H. (2016). Analisis Determinan Faktor Tabungan. Asian Journal of Inovation and Enterpreneurship, Vol. 01, No. 02, September 2016, hal 219-233.

Rohmah, I.R.Q. (2015). Pengaruh Tingkat Kepercayaan, Bagi Hasil, Kesesuaian Hukum Syariah, Reputasi Bank, dan Perolehan Informasi terhadap Keinginan Menambah Tabungan Mudharabah di Bank Rakyat Indonesia Syariah Cabang Jember. Skripsi. Universitas Jember.

Rosa, A. (2016). The Importance of Bank's Reputation in the Selection of Banking Products in the Opinion of Middle Pomeranian Farmers. Journal of Agribussines and Rural Development 2016, hal 399-406.

Soeratno, \& Lincolin, A. (2008). Metode Penelitian untuk Ekonomi dan Bisnis. Yogyakarta: UPP STIM YKPN.

Sugiyono. (2010). Metode Penelitian Pendidikan Pendekatan Kuantitatif, kualitatif, dan $R \& D$. Bandung: Alfabeta.

Sumarwan, U. (2011). Perilaku Konsumen. Bogor: Ghalia Indonesia. 